\title{
Study of Haematological Parameters in Pre and Post-Treated Dogs with Chemotherapy by Doxorubicin and Vincristine in Canine Transmissible Venereal Tumour
}

\author{
Anup Yadav', Praveen Kumar ${ }^{2 *}$, N.S. Bugalia', Umed Singh Mehra', \\ Rajendra Yadav ${ }^{3}$ and Pankaj Kumar ${ }^{4}$ \\ ${ }^{1}$ Department of Veterinary Gynaecology and Obstetrics ${ }^{2}$ Department of Veterinary Medicine \\ (LUVAS, Hisar), Haryana, India \\ ${ }^{3}$ RVDEC, Mahendergarh (LUVAS, Hisar), Haryana, India \\ ${ }^{4}$ Disease Investigation Laboratory, Rohtak (LUVAS, Hisar), Haryana, India \\ *Corresponding author
}

\section{A B S T R A C T}

\begin{tabular}{|l|}
\hline Ke y w or d s \\
$\begin{array}{l}\text { Doxorubicin, Vincristine, } \\
\text { Transmissible venereal } \\
\text { tumour }\end{array}$ \\
\hline Article Info \\
\hline $\begin{array}{l}\text { Accepted: } \\
22 \text { October } 2018 \\
\text { Available Online: } \\
10 \text { November } 2018\end{array}$ \\
\hline
\end{tabular}

\section{Introduction}

Canine transmissible venereal tumour (TVT) popularly called as venereal granuloma is the longest-lived cancer 'clone' recorded in literature. Russian veterinarian Nowinsky described TVT in year1876 in canines. The tumor contradicts the current view that cancer cells generate more mutations and inevitably become more aggressive if untreated (Murgia et al., 2006). Transmission of TVT occurs by direct contact through coitus and tumour cells are seeded onto mucous membrane (Bloom,
The present study was carried out in twenty-four dogs irrespective of age, breed, sex affected with canine transmissible venereal tumour (TVT). Affected dogs were divided equally into three groups viz. vincristine therapy (Group I) with 7 day cycle and doxorubicin therapy consisting two groups i.e. Group II with 14 day cycle and group III with 21 day cycle. Pre treatment blood sample collection was done before administration of drug i.e. Day 0, 7, 14 in Group I, Day 0, 14, 28 in Group II and Day 0, 21, 42 in Group III. Hematological parameters viz. Haemoglobin, Total erythrocytes count (TEC) and Total luecocyte count (TLC) was undertaken for study. Non-significant but declining trend of $\mathrm{Hb}$ concentration, leucopenia and reduction in total erythrocytes count was observed post treatment in Doxorobucin and vincristine chemotherapy.
1954 and Dass, 1986). Chemotherapy has been shown to be the most effective and practical therapy, with vincristine sulfate being the most frequently used drug (Calvet $e t$ al., 1982). TVT responds well with Vincristine as a chemotherapeutic agent (Cohen., 1985 and Johnston., 1994). Four to five cycles administered at weekly interval usually ensures a complete cure. Other chemotherapeutic agents like cyclophosphamide, vinblastine and methotrexate have also been used alone or in combination in treatment regimen 
(Richardson, 1981., Johnston, 1991., Brown et al., 1981; Yang et al., 1991). Resistant cases of these drugs (cyclophosphamide, vincristine sulphate, vinblastine and methotrexate) can be treated with doxorubicin (Richardson., 1981; Souza et al., 1998). Haemoglobin decline in TVT affected dogs following chemotherapy was consequential to bone marrow suppressive effect of cytotoxic drugs affecting erythropoiesis (Satoskar et al., 1995; Sandhu, H.S. and Rampal, S., 2006).

Precursor cells of the bone marrow are suppressed by cytotoxic drugs resulting in reduced production of leucocytes. Decreased TLC values following chemotherapy with vincristine and doxorubicinin dogs affected with TVT was due to potent myelo suppressive action of these drugs and hence distinct leucopenia observed (Sandhu and Rampal, 2006). Decreased TEC values following chemotherapy in TVT affected dogs were due to suppression of erythropoiesis in bone marrow (Theilen and Madewell, 1979 and Dinesh et al., 1993).

\section{Materials and Methods}

Twenty four dogs (male and female) with history of bleeding from genital organs were selected. Blood samples were collected from the distal cephalic vein or saphenous vein of male and female dogs from all three groups. Blood samples were collected on day of treatment before administration of drug. Site of blood collection was shaved and cleaned with antiseptic and $2 \mathrm{ml}$ blood was collected by using 20 and 22 or 24 gauge scalp vein set in heparinized glass tubes for complete blood count (CBC). Hematological parameters viz. Total erythrocytes count (TEC) and Total luecocyte count (TLC) were done by standard methods. Haemoglobin was estimated by using Sahli's haemoglobinometer. CBC analysis was performed on day of drug administration.

\section{Results and Discussion}

\section{Haemoglobin (Hb)}

TVT affected dogs treated with vincristine sulphate showed marginal decreasing trend of $\mathrm{Hb}$ from Day 0 to Day 14 post treatment but $\mathrm{Hb}$ value were within the normal range (Group I). Recorded declining pattern of $\mathrm{Hb}$ during post-treatment period in vincristine group simulates with the earlier observations (Padile et al., 1998).

Dogs treated with doxorubicin hydrochloride also registered slight decreasing pattern of $\mathrm{Hb}$ during post treatment period. Haemoglobin $\mathrm{Hb}$ values were within the normal physiological range in both treatment regimens of doxorubicin (Group II \& III). However, Talker (2001) also reported gradual reduction in $\mathrm{Hb}$ with doxorubicin therapy in TVT affected dogs but within normal range.

Satoskar et al., (1995) observed small sized rubric blast (immature rubriblast) consequential to reduction of erythropoietin level. The observed declining pattern of $\mathrm{Hb}$ in TVT affected dogs following vincristine sulphate and doxorubicin hydrochloride therapy was consequential to bone marrow suppressive effect of cytotoxic drugs affecting erythropoiesis (Satoskar et al., 1995; Sandhu, H.S., Rampal, S., 2006) (Fig. 1 and Table 1).

\section{Total leucocyte Count (TLC)}

Vincristine therapy in TVT affected dogs registered continuous decreasing pattern of TLC during post-treatment period. Recorded post-treatment leucopenia in this group concurs with the earlier observations in canine TVT after vincristine therapy (Calvert et al., 1982; Zezza et al., 1996 and Padile et al., 1998). However, Coppoc et al., (1982) reported that TLC values were not affected with Vincristine therapy. 
Table.1 Hematological parameters (Mean \pm S.E.) in TVT affected dogs during pre and post Treatment period (Groups I, II \& III)

\begin{tabular}{|c|c|c|c|c|c|c|c|c|c|}
\hline \multirow[t]{2}{*}{ Parameter } & \multicolumn{3}{|c|}{$\begin{array}{c}\text { Group I (vincristine) } \\
\qquad(\mathrm{n}=\mathbf{8})\end{array}$} & \multicolumn{3}{|c|}{$\begin{array}{l}\text { Group II (doxorubicin) } \\
\qquad(\mathrm{n}=\mathbf{8})\end{array}$} & \multicolumn{3}{|c|}{$\begin{array}{c}\text { Group III } \\
\text { (doxorubicin) } \\
(\mathbf{n}=\mathbf{8})\end{array}$} \\
\hline & $\begin{array}{c}\text { Day } 0 \\
\left(1^{\text {st }}\right. \\
\text { dose })\end{array}$ & $\begin{array}{l}\text { Day } 7 \\
\left(2^{\text {nd }}\right. \\
\text { dose })\end{array}$ & $\begin{array}{c}\text { Day14 } \\
\text { (3 }^{\text {rd }} \\
\text { dose })\end{array}$ & $\begin{array}{l}\text { Day } 0 \\
\left(1^{\text {st }}\right. \\
\text { dose })\end{array}$ & $\begin{array}{c}\text { Day14 } \\
\left(2^{\text {nd }}\right. \\
\text { dose })\end{array}$ & Day28 & $\begin{array}{l}\text { Day } 0 \\
\left(1^{\text {st }}\right. \\
\text { dose })\end{array}$ & $\begin{array}{c}\text { Day21 } \\
\left(2^{\text {nd }}\right. \\
\text { dose })\end{array}$ & $\begin{array}{l}\text { Day42 } \\
\left(3^{\text {rd }}\right. \\
\text { dose })\end{array}$ \\
\hline $\mathrm{Hb}(\mathrm{gm} / \mathrm{dl})$ & $\begin{array}{c}14.12 \pm \\
0.42\end{array}$ & $\begin{array}{c}13.53 \pm \\
0.47\end{array}$ & $\begin{array}{c}12.95 \pm \\
0.43\end{array}$ & $\begin{array}{c}13.24 \pm \\
0.37\end{array}$ & $\begin{array}{c}12.88 \pm \\
0.32\end{array}$ & $\begin{array}{c}12.70 \pm \\
0.29\end{array}$ & $\begin{array}{c}13.32 \pm \\
0.66\end{array}$ & $\begin{array}{c}12.88 \pm \\
0.59\end{array}$ & $\begin{array}{c}12.59 \pm \\
0.63\end{array}$ \\
\hline TLC(thousand/cumm) & $\begin{array}{c}19.22 \pm \\
1.80\end{array}$ & $\begin{array}{c}18.38 \pm \\
1.88\end{array}$ & $\begin{array}{c}18.32 \pm \\
2.07\end{array}$ & $\begin{array}{c}18.14 \pm \\
1.34\end{array}$ & $\begin{array}{c}16.60 \pm \\
1.40\end{array}$ & $\begin{array}{c}15.11 \pm \\
1.22\end{array}$ & $\begin{array}{c}17.70 \pm \\
1.58\end{array}$ & $\begin{array}{c}16.60 \pm \\
1.40\end{array}$ & $\begin{array}{c}14.02 \pm \\
9.84\end{array}$ \\
\hline TEC(million/cumm) & $\begin{array}{c}6.92 \pm \\
0.23\end{array}$ & $\begin{array}{c}6.73 \pm \\
0.15\end{array}$ & $\begin{array}{c}6.38 \pm \\
0.18\end{array}$ & $\begin{array}{l}7.44 \pm \\
0.10^{\mathrm{a}}\end{array}$ & $\begin{array}{l}7.18 \pm \\
0.04^{\mathrm{a}}\end{array}$ & $\begin{array}{l}6.70 \pm \\
0.12^{b}\end{array}$ & $\begin{array}{l}7.08 \pm \\
0.18^{\mathrm{a}}\end{array}$ & $\begin{array}{l}6.58 \pm \\
0.14^{b}\end{array}$ & $\begin{array}{l}6.30 \pm \\
0.15^{b}\end{array}$ \\
\hline
\end{tabular}

Day 0- pretreatment period; Days 7, 14, 28, 21, 42- post-treatment period

Means with different superscripts $(a, b)$ within the group in a row differ significantly $(p<0.05)$

Fig.1 Histogram showing haemoglobin values (Mean \pm S.E.)in TVT affected dogs during pre- and post-treament period (Groups I, II \& III)

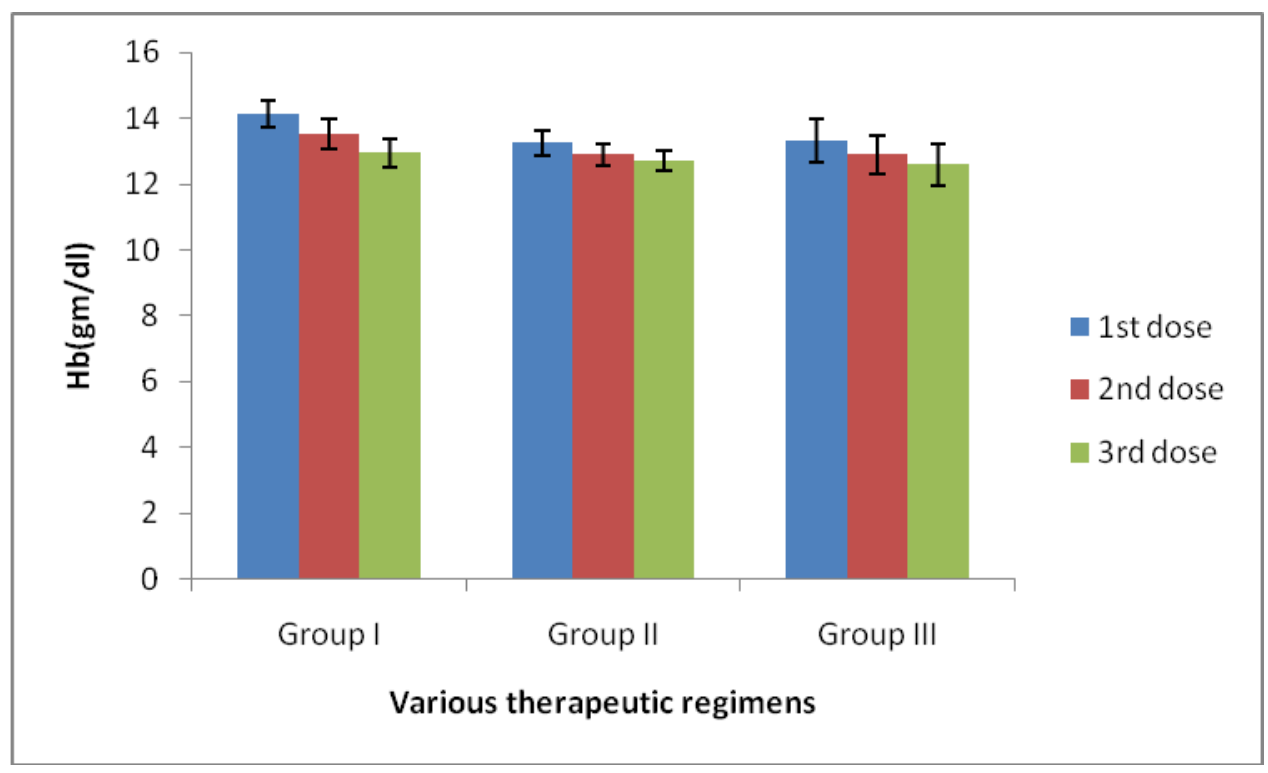

Dogs treated with doxorubicin regimen also showed gradual but non-significant declining trend during post-treatment period. Similarly, marginal leucopenia was recorded following doxorubicin therapy in TVT affected dogs (Benjamin, 1979).

However, Todorova et al., (2005) reported significant leucopenia in dogs after administration of second dose of Doxorubicin hydrochloride. Dobson and Gorman (1993) reported that cytotoxic drugs suppress the replicating precursor cells of the bone marrow resulting in reduced production of leucocytes.

Recorded decreased TLC values following vincristine and doxorubicin therapy in dogs affected with TVT was due to potent myelo 
suppressive action of vincristine and doxorubicin and hence distinct leucopenia observed (Sandhu and Rampal, 2006).

\section{Total erythrocyte count (TEC)}

Consistent non-significant decreasing trend of TEC was observed in TVT affected dogs during post-treatment period of vincristine sulphate and values remained within normal range from Day 0 to Day 14.

Dogs treated with doxorubicin regimens (Group II \& III) showed significant fall in TEC values during post-treatment period but within the normal range. Similarly, Todorova et al., (2005) and Gadmade (2006) recorded significant reduction in TEC following Doxorubicin hydrochloride therapy.

Decreased TEC following chemotherapy in TVT dogs was due to suppression of erythropoiesis in bone marrow (Theilen and Madewell, 1979 and Dinesh et al., 1993). Jumean et al., (2006) suggested that erythrocytic cell abnormalities are also observed invinca alkaloid toxicity.

Non-significant declining trend was observed in $\mathrm{Hb}$, TLC and TEC following vincristine therapy (Group I) and doxorubicin therapy (Group II and III).

In conclusion, venereal tumour problem is still very important disease in sexually active population of straydogs because of its sexually transmitting nature and its incidence is rapidly growing in tropical subtropical areas including India.

Although its clinical signs and symptoms are much indicate of its diagnosis but continuous blood loss, immune-suppression and bone marrow depression by chemotheurapeutic drugs viz. Vincristine and Doxorubicin caused decline in $\mathrm{Hb}$, TLC,TEC values. So in future reference early diagnosis, timely and cost effective treatment strategy must be adopted to control this sexually transmitted disease.

\section{References}

Benjamin, M.M. (1979). Haematology Outline of Veterinary Clinical Pathology 3 edn. lowa State Univ Press' Ames, lowa. PP: 75-94.

Bloom, F. (1954). Pathology of Dog and cat. (American Veterinary Publication Eastern lllinois), 275.

Boscos, C., Ververidis. H.N., Stefanakis, A., Saratsis, P., Stamou, A.I., \& Krambovitis, E. (2004). Serum oestradiol-17 $\beta$, progesterone and respective cytosol receptor concentrations in bitches with spontaneous pyometra. Theriogenology 62, 614-623.

Brown N.O., MacEwen E.G., Calvert C.A. (1981). Transmissible venereal tumor in the dog. California Vet; 3:6-10.

Calvert, C.A., Leifer, C.E. and MacEwen, E.G. (1982). Vincristine for treatment of transmissible venereal tumours in the dog. J. of the Am.Vet.Med. Assoc., 181: 163-164

Cohen D. (1985). The canine transmissible venereal tumor: A unique result of tumor progression. Adv Cancer Res; 43:75-112.

Coppoc, G. L. (1982). Chemotherapy of neoplastic diseases in Johnes Veterinary: Pharmacology, By Booth N. H. and Mc. Donald.5th Edition pp789793.

Dass, L.L., Sayay, P.N., Khan, A.A., and Jha, G.J., (1986). Malignant transmissible venereal tumour. Canine Practice, 13:15-18.

Dinesh, N.M.; Rangnath, B.N., Jayadevappa, S.M., and Srinivas, C.L. (1993).Gross and microscopic changes in 
transmissible venereal tumour following vincristine sulphate therapy. Ind Vet J. 70(7):609-611.

Dobson, J. M., and Gorman, N.T. (1993), Cancer chemotherapy in small animal practice. Blackwell scientific publication London: 67-154.

Gadmade. (2006). Studies on unusual vaginal tumours in bitches with special Reference in bitches with special reference to therapeutic measures. M.V.Sc. thesis work submitted to Maharashtra Animal \& Fishery.

Johnson, C.A. (1994). Infecçõesgenitais e tumor venéreotransmissível. In: Nelson RW, Couto CG, eds. Fundamentos de MedicinaInterna de PequenosAnimais. Rio de Janeiro: Guanabara Koogan; 525.

Johnston S.D. (1991). Performing a complete canine semen evaluation in a small animal hospital. Vet Clin North Am Small AnPract; 21(3):545-551.

Jumean, H. G.; Camitta, B., Holcenberg, J. and Hodach, A. (2006). Desacetyl Vinblastine amide sulfate induced erythropoiesis Cancer 44(1): 64-68.

Murgia, C., Pritchard, J.K., Kim, S.Y., Fassati, A. and Weiss, R.A. (2006). Clonal origin and evolution of a transmissible cancer. Cell, 126: 477487.

Novinsky, L. C. (1876). Tumor transplantation studies in dog. A report of 10 cases and a review of literature. Journal of comparative Pathology 96(6): 623-635.

Oser, B.L. (1965). Blood analysis of Hawk's Physiological Chemistry, 14th Edition, McGraw Hill Publishing Company, New York; 975-1152.

Padile, R. D., Panchbhai, V.S., Bhokre, A.P., Jadhav, P.T., and Bapat, S.T. (1998). Heaematological and blood biochemical changes in dog after vincristine administration for treatment of venereal granuloma. Ind. J. of Vet. Surg. 1:47.

Richardson, R.C. (1981). Canine transmissible venereal tumour. Comp ContinEducPract Vet; 3:951-956.

Sandhu, H.S., Rampal, S., (2006). Essentials of Veterinary Pharmacology and Therapeutics First Edition pp: 13591381.

Satoskar, R.S., Bhandarkar S.D. and Airnapure S. S. (1995). Pharmacology and Pharmaco therapeutics revised Fourteenth Edition. 734.

Souza, F.F., de, Tinucci-Costa, M., FariaJr, D (1998). Doxorubicin treatment for recurrent canine transmissible veneral tumor. In: Proceedings of the XXIII Congress of the World Small Anim Vet Assoc; 772.

Talekar, S.H. (2001). Comparative study of surgical excision and chemotherapeutic agents in the treatment of mammary tumours in canine. Unpublished M.V.Sc, thesis submitted to the $\mathrm{Dr}$ Punjabrao Deshmukh Krishi Vidyapeeth, Akola.

Theilen, G.H. and Madewell, B.R. (1987).Veterinary Cancer Medicine. Clinical Application of Cancer Chemotherapy, 2nd edn, (Lea and Febiger, Philadelphia), 183-196.

Tinucci-Costa, M. (1999). Tumor venéreotransmissível: estudosimunohistoquímicos e de transplantaçõesxenogênicas $\mathrm{e}$ alogênicas. Ph D Thesis Faculty of Medicine. San Pablo University, RibeirãoPreto, 1999; 144.

Todorova, G., Simeonov, R. and Dinev, D. (2005). Efficacy and toxicity of doxorubicin and cyclophosphamide chemotherapy in dogs with spontaneous mammary tumors. Trakia j. of sci. 3:5158.

Yang, T.J., Palker, T.J., Harding, M.W. (1991). Tumor size, leukocyte 
adherence inhibition and serum levels of tumor antigen in dogs with the canine transmissible venereal sarcoma. Cancer Immunol. Immunoth, 33:255-256.

Zezzaet, N. L., Polegato, E.P., Dos, S. and Peres, J. A. (1996). Treatment of the sticker tumour (Transmissible venereal tumour) with oncovin. Vet.Bull., 66: 148

\section{How to cite this article:}

Anup Yadav, Praveen Kumar, N.S. Bugalia, Umed Singh Mehra, Rajendra Yadav and Pankaj Kumar. 2018. Study of Haematological Parameters in Pre and Post-Treated Dogs with Chemotherapy by Doxorubicin and Vincristine in Canine Transmissible Venereal Tumour. Int.J.Curr.Microbiol.App.Sci. 7(11): 2732-2737. doi: https://doi.org/10.20546/ijcmas.2018.711.313 